\section{It is time to become a member of the Canadian Thoracic Society}

$\mathrm{T}_{\mathrm{h}}^{\mathrm{h}}$ he Canadian Thoracic Society (CTS) promotes lung health by supporting the respiratory community through leadership, collaboration, research, learning and advocacy, and by promoting the best respiratory practices in Canada. This mission statement sustains the overall vision of the CTS to improve lung health for Canadians, in conjunction with the Canadian Lung Association (CLA) and the Canadian Respiratory Health Professionals (CRHP).

It is evident that many of you agree with these goals. Membership in the CTS is at an all-time high this year. This is good news. We have never had so many join our organization. The reasons for the increased membership are likely many, but I believe the increase reflects the renewed enthusiasm and the new direction of the organization. It also importantly highlights the pressing necessity for a strong pan-Canadian voice speaking to the needs of our members, our patients and our interests. This is today's reality.

Recent efforts within the CTS have concentrated on building an organization that is able to effectively respond to these realities and these needs. The efforts have been successful as a result of the strong leadership of Gerard Cox, Gordon Ford and others - individuals who have asked, listened and learned, and then worked hard together to strengthen the CTS. The organization today is very different from the CTS in the past few years.

The task of building the CTS is ongoing and is not finished. While the CTS is approaching its 50th birthday (perhaps fittingly, surviving a 'mid-life crisis' two-and-a-half years previously) and has a very proud history, there is so much more that can and will be accomplished. For this to be lasting and truly successful, we need to further build our membership so that everyone who is eligible to join the CTS becomes an engaged and active member of the organization.

So why should you join the CTS? Here are some practical benefits of membership:

- Fifteen per cent reduced membership fees (25 Euros) for the European Respiratory Society (and associated reduced registration fees [150 Euros] for the annual European Respiratory Society Congress);

- Free admission (including one guest) to the CTS Social at the American Thoracic Society conference;

- Reduced registration fees for the American College of Chest Physicians (ACCP) Chest Conference (equivalent to ACCP member's rate, a US $\$ 300$ value);

- Free admission to the CTS Banquet at the ACCP Chest Conference;

\section{Le temps est venu de vous joindre à la Société canadienne de thoracologie}

T a Société canadienne de thoracologie (SCT) encourage la santé Lrespiratoire et appuie la pneumologie par son leadership et ses activités de collaboration, de recherche, de formation et de défense des intérêts des groupes concernés et elle promeut l'excellence en pneumologie au Canada. Cet énoncé de mission concorde avec la vision globale de la SCT qui est d'améliorer l'état de santé respiratoire des Canadiens en collaborant avec l'Association pulmonaire du Canada (APC) et les professionnels canadiens en santé respiratoire (PCSR).

Vous êtes sans contredit nombreux à soutenir ces objectifs car les adhésions à la SCT ont atteint un record cette année. Quelle bonne nouvelle! Nous n'avons jamais recruté autant de nouveaux membres. Ce phénomène a sûrement plusieurs explications, mais je crois qu'il reflète avant tout un enthousiasme renouvelé envers la pneumologie et la nouvelle orientation de l'organisation. Les nouvelles adhésions rappellent on ne peut mieux le besoin de nous exprimer d'une voix pancanadienne forte sur les besoins de nos membres et de nos patients et de militer pour la défense de nos intérêts communs. Voilà la réalité d'aujourd'hui.

Les récents efforts déployés au sein de la SCT ont été axés sur sa consolidation afin qu'elle soit capable de répondre efficacement à ces réalités et à ces besoins. Ses efforts ont porté fruit grâce à l'excellent leadership de Gerard Cox, de Gordon Ford et d'autres, qui ont su poser des questions, écouter et apprendre, et qui ont ensuite travaillé sans relâche pour donner de nouvelles bases à la SCT. L'organisation actuelle est très différente de celle des années passées.

Cette tâche de reconstruction de la SCT se poursuit; elle n'est pas terminée. Après avoir traversé une crise que l'on pourrait qualifier d'existentielle il y a deux ans et demi, la SCT est sur le point de célébrer son $50^{\mathrm{e}}$ anniversaire et si elle a une histoire dont elle peut être très fière, il lui reste encore beaucoup à accomplir et elle compte bien y arriver. Pour que cette transformation soit durable et couronnée de succès, nous devrons miser davantage sur les adhésions et faire en sorte que quiconque y est admissible en devienne un membre engagé et actif.

Donc, pourquoi devriez-vous vous joindre à la SCT? Voici quelques-uns des nombreux avantages du statut d'adhérent :

- Réduction de $15 \%$ sur les frais d'adhésion à l'European Respiratory Society (25 euros) (accompagnée d'une réduction sur les frais d'inscription [150 euros] à son congrès annuel);

- Admission gratuite (avec un invité) à l'activité sociale de la SCT en marge de la Conférence de l'American Thoracic Society;

- Réduction sur les frais d'inscription à la Conférence de thoracologie de l'American College of Chest Physicians (ACCP) équivalant au taux accordé aux membres de l'ACCP, une valeur de 300 \$US; 
- Reduced registration fees for the Canadian Respiratory Conference, June 19 to 22, 2008, in Montreal;

- Free admission to the CTS Banquet at the Canadian Respiratory Conference in Montreal;

- Free on-line access to the Canadian Respiratory Journal, a $\$ 205$ per year value;

- Access to educational and practice resources (patient and practice tools, Web site links, clinical guidelines and slide kits);

- Collaboration with a national network of respiratory physicians, researchers and investigators who are studying and promoting lung health across Canada; and

- Participation and leadership opportunities in the CTS committees, guideline development and research activities.

While some of these may not apply to everyone, it is hard to shun these benefits for a low annual membership fee of $\$ 100$ (\$25 for Residents and Fellows).

Although there have been missteps and unpleasant experiences in the past, it is now time to live in the present. While it is important to learn from the past, we should refrain from only looking backwards and reminiscing hurts in the past 10 or 20 years. That will not help. It is time for us to work together to build a future that can benefit us all. Let us work together to build an organization we fully deserve, and that makes us proud.

Here are some of the current activities of the CTS:

- Organizing the 1st Annual Canadian Respiratory Conference in Montreal, June 19 to 22, 2008, in collaboration with the Canadian COPD Alliance, the CRHP and the CLA. You will be hearing much more about this in the near future - but for now, please mark your calendars;

- Developing more Continuing Medical Education initiatives (Royal College of Physicans and Surgeons of Canada [RCPSC] MainCert accredited - the CTS is an accredited RCPSC provider);

- An ongoing CTS scientific program linked with the annual ACCP Chest Conference each fall. We will continue to work closely with the ACCP. A significant benefit of this strong partnership is that the ACCP has committed to holding the Chest Conference in Canada every five years (Vancouver 2010, Montreal 2015 - both exceptional venues for an international conference);

- Developing new research activities and support for CTS members, together with increased and effective advocacy for enhanced research funding and partnerships - these will become 'visible' in 2008. The lack of significant and sustained research funding is one of the most glaring deficiencies that must be confronted by the CTS;

- Creating the Canadian Respiratory Guidelines Committee;

- Developing more educational and clinical practice resources;
- Admission gratuite au banquet de la SCT en marge de la Conférence de thoracologie de l'ACCP;

- Réduction sur les frais d'inscription à la Conférence canadienne de pneumologie, du 19 au 22 juin 2008 à Montréal;

- Admission gratuite au banquet de la SCT à l'occasion de la Conférence canadienne de pneumologie à Montréal;

- Accès en ligne gratuit au Canadian Respiratory Journal, d'une valeur de 205 \$ par année;

- Accès à des ressources didactiques et pratiques (outils pour les patients et outils de pratique, liens vers des sites Web, des directives cliniques et des jeux de diapositives);

- Collaboration avec un réseau national de médecins spécialistes, chercheurs et investigateurs en pneumologie qui se consacrent à l'étude et à la promotion de la santé respiratoire partout au Canada; et

- Possibilité de se joindre à divers comités, de participer à des activités de recherche et à l'élaboration des directives de la SCT ou de diriger ces comités/activités.

Même si ces nombreux avantages ne concernent pas tout le monde, pour des frais d'adhésion annuels d'aussi peu que 100 \$ (25\$ pour les résidents et les fellows), difficile de résister.

Il y a eu quelques erreurs de parcours et expériences désagréables autrefois, mais il faut vivre au présent. Sachons tirer les leçons qui s'imposent, abstenons-nous de regarder en arrière et de revenir sur les accrocs des dix ou vingt dernières années. Rien ne sert de ressasser le passé. Il est temps maintenant de travailler tous ensemble à préparer un avenir prometteur pour le plus grand nombre. Serrons-nous les coudes pour nous doter de l'organisation que nous méritons de plein droit et dont nous pouvons être fiers.

Voici quelques-unes des activités actuelles de la SCT :

- Organisation de la Ire Conférence annuelle canadienne de pneumologie à Montréal, du 19 au 22 juin 2008, en collaboration avec l'Alliance des BPOC du Canada, les PCSR et l'APC. Vous entendrez encore beaucoup parler de cet événement très bientôt, mais pour l'instant, notez-le à vos agendas.

- Mettre au point d'autres projets de formation médicale continue (accrédités par le Collège royal des médecins et chirurgiens du Canada [CRMCC] - la SCT est un fournisseur accrédité du CRMCC).

- Un programme scientifique permanent hébergé par la SCT est relié à la Conférence de thoracologie de l'ACCP chaque automne. Nous continuerons de travailler étroitement avec l'ACCP; ce solide partenariat a pour avantage non négligeable que l'ACCP s'est engagée à tenir sa conférence de thoracologie tous les cinq ans au Canada (Vancouver 2010, Montréal 2015 - deux sites exceptionnels pour une conférence internationale).

- Mettre au point de nouvelles activités de recherche et de soutien pour les membres de la SCT, y compris une promotion accrue et efficace de leurs intérêts afin de stimuler le financement et les collaborations de recherche qui devraient se matérialiser en 2008. Le manque de financement important et stable pour la recherche est l'une des importantes lacunes que la SCT a l'intention de combler. 
- More effective dissemination and implementation of clinical practice guidelines and information;

- New clinical practice guideline offerings and updates, ie, home mechanical ventilation, chronic obstructive pulmonary disease and asthma;

- Offering a wider variety of RCPSC Section 1 Continuing Medical Education/Continuing Professional Development accredited programs;

- Supporting the valuable Respiratory Fellow Examination Preparation Course;

- Improving promotion of the successful National Resident/Fellow Research Competition;

- Providing opportunities for Division Heads, Respirology Program Directors and Residents/Fellows to meet;

- Continuing to strengthen and build relationships with the CLA and the CRHP;

- Continuing our leadership role in the National Lung Health Framework; and

- Organizing efforts and activities that will celebrate the 50th anniversary of the CTS next year.

These are a sampling of activities currently being undertaken by the CTS.

In the next few months, you will be receiving a new brochure which further speaks to the value of CTS membership. If you are already a member, please be sure to renew, and do not forget to encourage your colleagues to do the same. If you are not yet a member of the CTS, I would extend a personal invitation for you to join the CTS.

But why wait for the brochure - you and your colleagues can join today. Visit the CTS Web site at <www.lung.ca/ctssct/home-accueil_e.php>. To register, just click on "Become a member of the Canadian Thoracic Society" button. You will also find more membership details, as well as information about the history and activities of the CTS (... the first 50 years!); professional activities; clinical practice guidelines; and important links to other clinical practice resources, information and materials, and the on-line Canadian Respiratory Journal.

Join the CTS today and become an important part of Canada's respiratory community!

Thank you so much. On behalf of the Executive and staff, I wish everyone the very best that summer has to offer.

Darcy D Marciniuk MD FRCPC FCCP President, Canadian Thoracic Society
- Créer un comité pour l'élaboration de directives canadiennes en pneumologie.

- Mettre au point des ressources en matière de formation et de pratique clinique.

- Diffuser et appliquer plus efficacement les directives de pratique clinique et l'information.

- Présenter et mettre à jour de nouvelles directives de pratique clinique, par exemple, ventilation mécanique à domicile, maladie pulmonaire obstructive chronique et asthme.

- Offrir une plus grande variété de programmes accrédités de formation médicale et de développement professionnel continus conformes à la Section 1 du CRMCC.

- Appuyer le cours préparatoire à l'examen des fellows en pneumologie.

- Améliorer la promotion du concours national de recherche pour les résidents et les fellows.

- Promouvoir les échanges entre les directeurs de départements, les directeurs de programmes de pneumologie, les résidents et les fellows.

- Continuer de consolider et de tisser des liens avec l'APC et les PCSR.

- Maintenir notre rôle de chef de file dans le domaine de la santé respiratoire; et

- Coordonner les efforts et les activités en vue de célébrer le $50^{\mathrm{e}}$ anniversaire de la SCT, l'an prochain.

C'était donc un aperçu des activités actuelles de la SCT.

D'ici les prochains mois, vous recevrez une nouvelle brochure qui explique plus en détail l'utilité de l'adhésion à la SCT. Si vous êtes déjà membre, assurez-vous de renouveler votre adhésion et n'oubliez pas d'encourager vos collègues à faire de même. Si vous n'êtes pas encore membre de la SCT, je vous invite personnellement à le devenir.

Mais pourquoi attendre la brochure? Vos collègues et vous pouvez adhérer dès maintenant. Consultez le site Web de la SCT, à l'adresse <www.lung.ca/cts-sct/home-accueil_e.php>. Pour vous inscrire, vous n'avez qu'à cliquer sur l'onglet Adhésion. Vous trouverez également plus de renseignements sur les adhésions et sur l'histoire et les activités de la SCT (... pour la première fois depuis 50 ans!), sur les événements professionnels, les directives de pratique clinique et d'importants liens pour accéder à d'autres ressources de pratique clinique, à des informations et à de la documentation et à la version en ligne du Canadian Respiratory Journal.

Joignez-vous à la SCT dès aujourd'hui et préparez-vous à jouer un rôle important dans la promotion de la santé respiratoire!

Merci infiniment. Au nom de l'exécutif et du personnel, je souhaite à tout le monde de bien profiter de ce que l'été a de mieux à nous offrir.

Darcy D. Marciniuk, M.D., FRCPC, FCCP Président, Société canadienne de thoracologie 


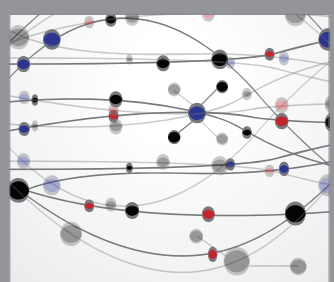

The Scientific World Journal
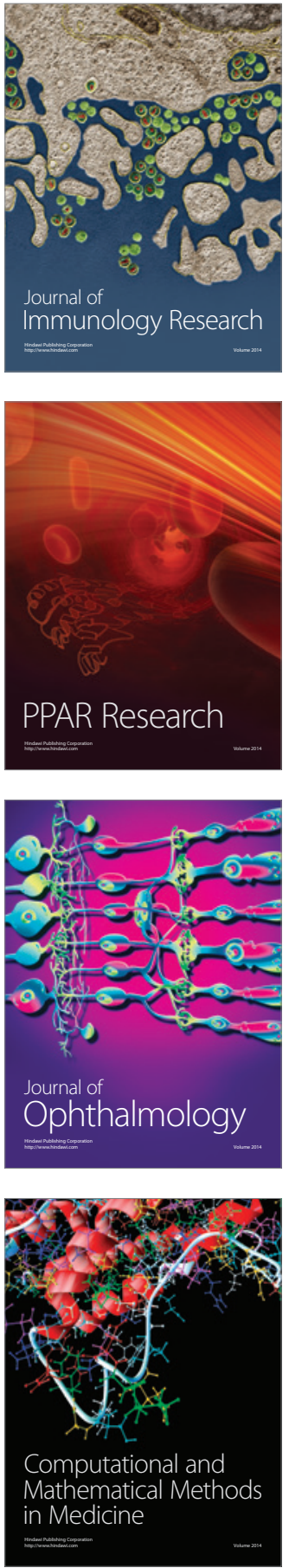

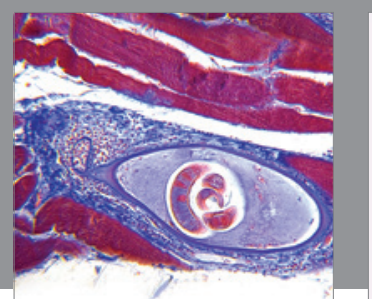

Gastroenterology Research and Practice

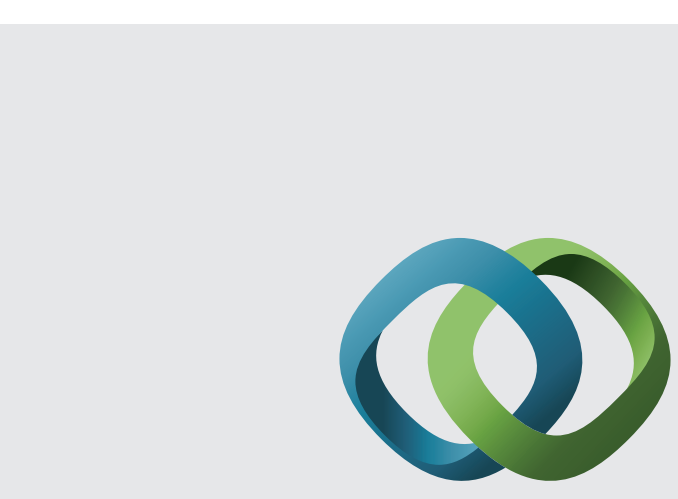

\section{Hindawi}

Submit your manuscripts at

http://www.hindawi.com
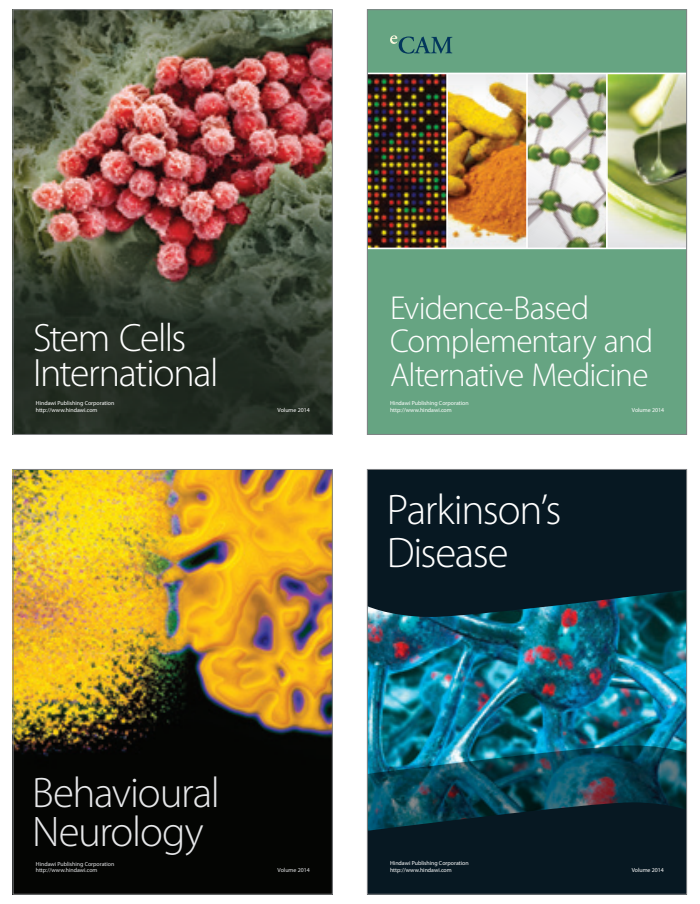
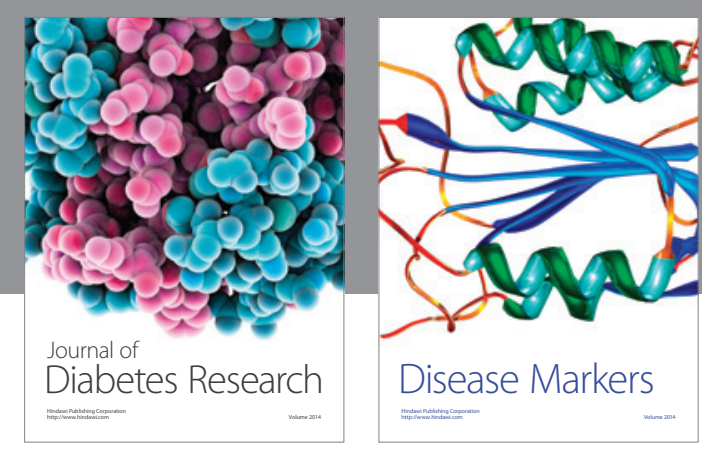

Disease Markers
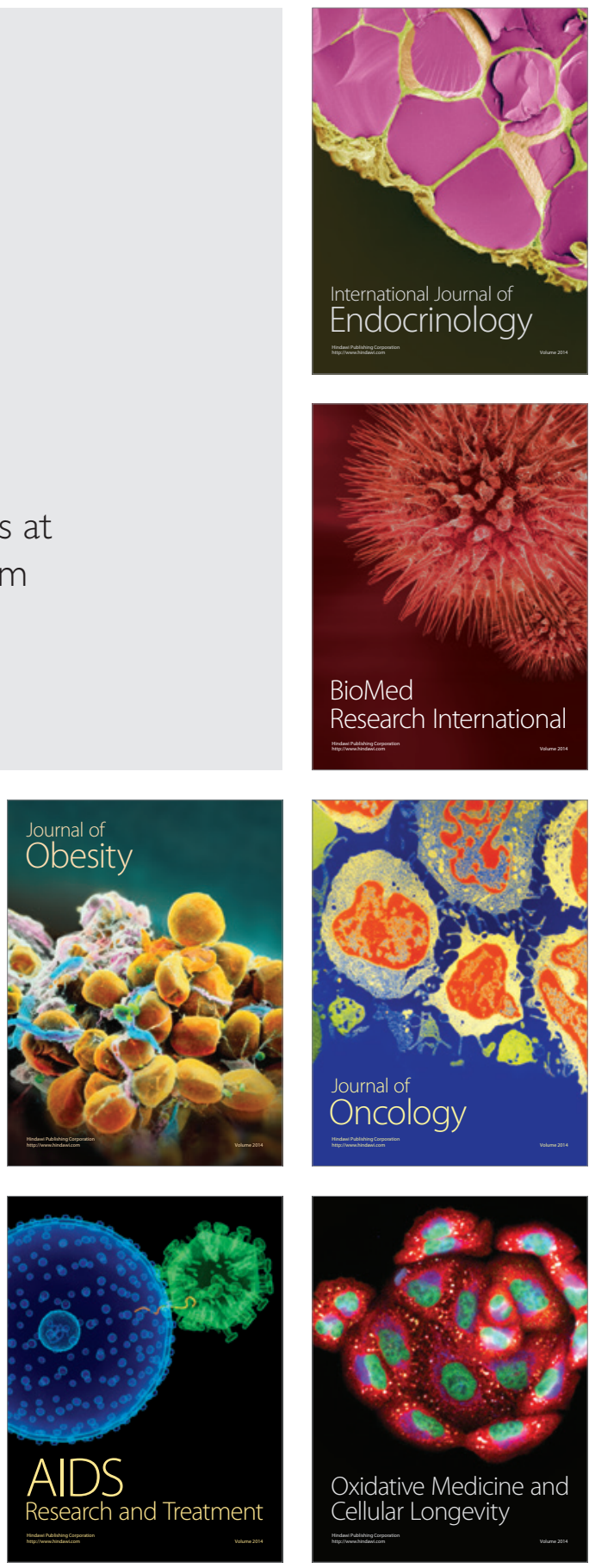